\author{
Zofia Mielecka-Kubien \\ Katarzyna Warzecha \\ Katedra Ekonometrii \\ Uniwersytet Ekonomiczny w Katowicach
}

\title{
Sytuacja demograficzno-społeczna wybranych miast województwa śląskiego w latach 2002 i 2009
}

\section{Streszczenie}

Celem badań jest określenie podobieństw miast województwa śląskiego liczących więcej niż 100 tys. mieszkańców (Bielsko-Biała, Bytom, Chorzów, Częstochowa, Dąbrowa Górnicza, Gliwice, Katowice, Ruda Śląska, Rybnik, Sosnowiec, Tychy i Zabrze), położonych w niezbyt dużej odległości geograficznej, w odstępie kilku lat. Podobieństwo badano z uwzględnieniem wybranych mierników sytuacji społeczno-gospodarczej miast i współczynników demograficznych w latach 2002 i 2009. Zastosowano metodę J. Czekanowskiego, a w celu stwierdzenia, które grupy miast znajdują się w lepszej lub gorszej sytuacji pod jakimś względem, porównano średnie wybranych mierników ogółem i dla wyróżnionych grup miast.

Badania przeprowadzono w następujących przekrojach: I - sytuacja demograficzno-społeczna, II - poziom zdrowotności i niektóre jego uwarunkowania, III - poziom zamożności, IV - poziom kultury i edukacji.

Najbardziej podobnymi do siebie miastami, a jednocześnie będącymi w najlepszej sytuacji społeczno-gospodarczej i demograficznej, były zarówno w 2002 r., jak i w 2009 r., mimo dzielącej je sporej odległości geograficznej, Bielsko-Biała i Częstochowa, przy czym miasto Bielsko-Biała cechowało się wysokim poziomem zamożności, nie wykazując pod tym względem podobieństwa do innych miast. Najbardziej podobnymi do siebie, a zarazem będącymi w niekorzystnej sytuacji miastami okazały się: Sosnowiec, Zabrze i Gliwice, leżące na terenie byłego Górnośląskiego Okręgu Przemysłowego.

Słowa kluczowe: metoda Czekanowskiego, sytuacja demograficzno-społeczna, miasta województwa śląskiego, metody taksonomiczne. 


\section{Wprowadzenie}

W województwie śląskim jest obecnie 12 miast o liczbie ludności przekraczającej 100 tys. (Bielsko-Biała, Bytom, Chorzów, Częstochowa, Dąbrowa Górnicza, Gliwice, Katowice, Ruda Śląska, Rybnik, Sosnowiec, Tychy i Zabrze). Miasta te odgrywają ważną rolę w rozwoju społeczno-ekonomicznym regionu, oddziałują one także w różny sposób na otaczające je mniejsze miasta i wsie. Trzy z wymienionych miast (Częstochowa, Gliwice i Sosnowiec) liczyły w badanym okresie ponad 200 tys. mieszkańców, a stolica regionu - Katowice, ponad 300 tys. Celem prezentowanych badań jest określenie podobieństw miast liczących więcej niż 100 tys. mieszkańców, położonych w obrębie tego samego województwa, a więc w niezbyt dużej odległości geograficznej, w odstępie kilku lat. Podobieństwa badano, biorąc pod uwagę mierniki opisujące sytuację społeczno-gospodarczą miast i współczynniki demograficzne w latach 2002 i 2009.

Zastosowano należącą do grupy metod analizy wielowymiarowej metodę J. Czekanowskiego, której graficzną prezentacją jest diagram Czekanowskiego' ${ }^{1}$. Pozwala on dokonać podziału obiektów (w tym przypadku miast) na grupy charakteryzujące się dużym stopniem wzajemnego podobieństwa, a otrzymane wyniki nie mają charakteru wartościującego, tzn. nie wskazują, które z grup obiektów są lepsze czy gorsze pod jakimś względem, informują jedynie o stopniu podobieństwa obiektów. Aby stwierdzić, które grupy miast znajdują się w lepszej lub gorszej sytuacji pod jakimś względem, porównano średnie ogólne i wyróżnionych grup miast dla branych pod uwagę mierników.

Odległość między badanymi obiektami w przestrzeni wielowymiarowej określano jako odległość euklidesową, a w przypadku grup częściowo pokrywających się wyboru odpowiedniego sposobu podziału miast dokonano, kierując się kryterium najkrótszej, dla możliwych grup przynależności danego miasta, przeciętnej odległości euklidesowej niejednoznacznie określonego miasta od innych miast.

Sytuację demograficzną, społeczną i ekonomiczną ludności miast województwa śląskiego (o liczbie mieszkańców powyżej 100 tys.) scharakteryzowano za pomocą zmiennych diagnostycznych opisujących różne jej aspekty² (tabela 1) i spełniających kryteria formalne i merytoryczne dotyczące zastosowania metody

${ }^{1}$ Diagram Czekanowskiego jest najstarszą metodą taksonomiczną, zastosowaną po raz pierwszy w 1909 r. przez polskiego antropologa J. Czekanowskiego. Więcej informacji na temat tej metody czytelnik może znaleźć w pracach: [Pluta 1986, Pociecha i in. 1988, Wolny 2009, Czekanowski 1909 i 1913, Heffner i Gibas 2007]. Do obliczeń wykorzystano program komputerowy MaCzek.

${ }^{2}$ Wybrane zmienne spełniają wymagane kryteria formalne i merytoryczne: są ważne z punktu widzenia prowadzonych badań, słabo skorelowane między sobą oraz cechują się odpowiednio wysoką zmiennością (współczynnik zmienności powyżej 10\%). 
Czekanowskiego; zmienne te zostały doprowadzone do postaci umożliwiającej ich porównywalność:

- destymulanty ${ }^{3}(D)$ zamieniono na stymulanty $(S)$ według kryterium:

$$
D \rightarrow S=x_{\max }-x_{i},
$$

przy czym $x_{\max }$ oznacza najwyższą zaobserwowaną wartość danej zmiennej;

- nominaty zamieniono na stymulanty (por. [Lipieta i in. 2000, s. 81]) według wzoru:

$$
S_{i j}=-\left|N_{n o m}-x_{i j}\right|,
$$

gdzie $N_{n o m}$ - oznacza pożądaną wartość nominanty;

- wszystkie zmienne diagnostyczne zestandaryzowano według formuły:

$$
x_{i j}=\frac{x_{j}-\bar{x}_{j}}{s_{j}},
$$

gdzie:

$x_{i j}$ - wartość $j$-tej zmiennej w $i$-tym obiekcie (mieście),

$\bar{x}_{j}$ - średnia arytmetyczna $j$-tej zmiennej,

$s_{j}$ - odchylenie standardowe $j$-tej zmiennej $(i=1,2, \ldots, n ; j=1,2, \ldots, m)$.

Dane statystyczne pochodzą z Banku Danych Regionalnych GUS w Warszawie.

\section{Wyniki badania empirycznego}

W tabeli 1 przedstawiono zmienne diagnostyczne ${ }^{4}$ charakteryzujące różne dziedziny społecznej, demograficznej i ekonomicznej sytuacji ludności badanych miast.

Tabela 1. Zbiór cech diagnostycznych

\begin{tabular}{|l|c|c|}
\hline \multicolumn{1}{|c|}{ Nazwa zmiennej } & \multicolumn{2}{c|}{ Symbol } \\
\cline { 2 - 3 } & 2002 & 2009 \\
\hline Pracujący ogółem na 1000 ludności $(S)$ & $X_{12}$ & $X_{19}$ \\
\hline Liczba bezrobotnych na 1000 pracujących $(D)$ & $X_{22}$ & $X_{29}$ \\
\hline Przeciętne miesięczne wynagrodzenie brutto $(S)$ & $X_{32}$ & $X_{39}$ \\
\hline
\end{tabular}

${ }^{3}$ Zmienna $(X)$ jest: stymulantą - im wyższa jest wartość tej zmiennej, tym lepsza jest sytuacja danego obiektu, nominantą - zmienna ma określoną najkorzystniejszą wartość zwaną wartością nominalną, lub destymulantą - im wyższa jest wartość tej zmiennej, tym gorsza jest sytuacja danego obiektu.

${ }^{4}$ Ostatnia cyfra subskryptu zmiennej oznacza rok (2 - 2002, 9 - 2009). Szczegółowy opis badań można znaleźć w pracy [Mielecka-Kubień i Warzecha 2010]. 
cd. tabeli 1

\begin{tabular}{|c|c|c|}
\hline \multirow{2}{*}{ Nazwa zmiennej } & \multicolumn{2}{|c|}{ Symbol } \\
\hline & 2002 & 2009 \\
\hline Dochody budżetu miasta na jednego mieszkańca w zł $(S)$ & $X_{42}$ & $X_{49}$ \\
\hline Wydatki budżetu miasta na jednego mieszkańca w zł $(S)$ & $X_{52}$ & $X_{59}$ \\
\hline Podmioty zarejestrowane w rejestrze Regon na 10 tys. ludności $(S)$ & $X_{62}$ & $X_{69}$ \\
\hline Nakłady inwestycyjne na jednego mieszkańca w zł $(S)$ & $X_{72}$ & $X_{79}$ \\
\hline Wartość brutto środków trwałych na jednego mieszkańca w zł $(S)$ & $X_{82}$ & $X_{89}$ \\
\hline Ścieki oczyszczane w \% wymagających oczyszczenia $(S)$ & $X_{92}$ & $X_{99}$ \\
\hline Emisja zanieczyszczeń gazowych w t/km² $(D)$ & $X_{102}$ & $X_{109}$ \\
\hline Emisja zanieczyszczeń pyłowych w $\mathrm{t} / \mathrm{km}^{2}(D)$ & $X_{112}$ & $X_{119}$ \\
\hline Zużycie wody w gospodarstwach domowych na jednego mieszkańca w m³ $(S)$ & $X_{122}$ & $X_{129}$ \\
\hline Zużycie gazu w gospodarstwach domowych na jednego mieszkańca w m³ $(S)$ & $X_{132}$ & $X_{139}$ \\
\hline Mieszkania oddane do użytku na 1000 ludności $(S)$ & $X_{142}$ & $X_{149}$ \\
\hline Liczba ludności na jednego lekarza $(D)$ & $X_{152}$ & $X_{159}$ \\
\hline Liczba ludności na jednego dentystę $(D)$ & $X_{162}$ & $X_{169}$ \\
\hline Liczba ludności na jedną pielęgniarkę $(D)$ & $X_{172}$ & $X_{179}$ \\
\hline Liczba ludności na jedną aptekę $(S)$ & $X_{182}$ & $X_{189}$ \\
\hline Łóżka w szpitalach ogólnych na 10 tys. ludności $(S)$ & $X_{192}$ & $X_{199}$ \\
\hline Liczba zgonów niemowląt na 1000 urodzeń żywych $(D)$ & $X_{202}$ & $X_{209}$ \\
\hline Liczba ludności na jedną placówkę biblioteczną $(S)$ & $X_{212}$ & $X_{219}$ \\
\hline Księgozbiór na 1000 ludności w woluminach $(S)$ & $X_{222}$ & $X_{229}$ \\
\hline Liczba czytelników na 1000 ludności $(S)$ & $X_{232}$ & $X_{239}$ \\
\hline Liczba ludności na jedno miejsce w kinach stałych $(S)$ & $X_{242}$ & $X_{249}$ \\
\hline $\begin{array}{l}\text { Liczba uczniów szkół podstawowych przypadających na jeden komputer } \\
\text { z dostępem do internetu }(D)\end{array}$ & $X_{252}$ & $X_{259}$ \\
\hline $\begin{array}{l}\text { Liczba uczniów gimnazjum przypadających na jeden komputer z dostępem } \\
\text { do internetu }(D)\end{array}$ & $X_{262}$ & $X_{269}$ \\
\hline Liczba uczniów liceów ogólnokształcących na 1000 ludności $(S)$ & $X_{272}$ & $X_{279}$ \\
\hline $\begin{array}{l}\text { Liczba uczniów ponadgimnazjalnych zasadniczych szkół zawodowych } \\
\text { na } 1000 \text { ludności }(S)\end{array}$ & $X_{282}$ & $X_{289}$ \\
\hline Liczba samochodów osobowych na 1000 ludności $(S)$ & $X_{292}$ & $X_{299}$ \\
\hline $\begin{array}{l}\text { Drogi publiczne powiatowe o twardej nawierzchni (na } 100 \mathrm{~km}^{2} \\
\text { powierzchni) w km }(S)\end{array}$ & $X_{302}$ & $X_{309}$ \\
\hline Gęstość zaludnienia $(D)$ & $X_{312}$ & $X_{319}$ \\
\hline Udział ludności w wieku przedprodukcyjnym $(S)$ & $X_{322}$ & $X_{329}$ \\
\hline
\end{tabular}


cd. tabeli 1

\begin{tabular}{|l|c|c|}
\hline \multicolumn{1}{|c|}{ Nazwa zmiennej } & \multicolumn{2}{c|}{ Symbol } \\
\cline { 2 - 3 } & 2002 & 2009 \\
\hline Współczynnik feminizacji (N) & $X_{332}$ & $X_{339}$ \\
\hline Współczynnik przyrostu naturalnego $(S)$ & $X_{342}$ & $X_{349}$ \\
\hline Standaryzowany współczynnik małżeństw $(S)$ & $X_{352}$ & $X_{359}$ \\
\hline Standaryzowany współczynnik rozwodów $(D)$ & $X_{362}$ & $X_{369}$ \\
\hline Standaryzowany współczynnik płodności kobiet $(S)$ & $X_{372}$ & $X_{379}$ \\
\hline Standaryzowany współczynnik zgonów mężczyzn $(D)$ & $X_{382}$ & $X_{389}$ \\
\hline Standaryzowany współczynnik zgonów kobiet $(D)$ & $X_{392}$ & $X_{399}$ \\
\hline Współczynnik salda migracji $(S)$ & $X_{402}$ & $X_{409}$ \\
\hline
\end{tabular}

Źródło: opracowanie własne.

Badania przeprowadzono dla całego zbioru współczynników (tabela 1) oraz następujących ich podzbiorów, charakteryzujących różne dziedziny społecznej, demograficznej i ekonomicznej sytuacji ludności wyróżnionych miast:

I - wszystkie zmienne,

II - zmienne charakteryzujące poziom zdrowotności i niektóre jego uwarunkowania w badanych miastach: $X_{9}-X_{11}, X_{15}-X_{20}, X_{31}, X_{38}-X_{39}$,

III - zmienne charakteryzujące poziom zamożności mieszkańców badanych miast: $X_{3}-X_{8}, X_{12}-X_{14}, X_{29}-X_{30}$,

IV - zmienne charakteryzujące poziom kultury i edukacji: $X_{21}-X_{28}$.

\section{Podobieństwo miast w 2002 roku}

Rys. 1-4 przedstawiają uporządkowane diagramy Czekanowskiego dla określonych wyżej zbiorów zmiennych diagnostycznych dla 2002 r. Biorąc pod uwagę cały zbiór zmiennych diagnostycznych, wyróżniono siedem grup miast: 1) Bielsko-Biała i Częstochowa, 2) Dąbrowa Górnicza i Gliwice, 3) Ruda Śląska, Zabrze i Bytom, 4) Sosnowiec i Chorzów (rys. 1). Pozostałe trzy miasta, tj. Katowice, Rybnik i Tychy, nie wykazują wystarczająco bliskiego podobieństwa z innymi miastami i tworzą grupy jednoelementowe.

Na podstawie macierzy odległości euklidesowych można stwierdzić, że najmniejsze różnice pod względem wartości branych pod uwagę zmiennych opisujących sytuację demograficzno-społeczną miast w 2002 r. dzielą Bielsko-Białą i Częstochowę, a największe - Katowice i Rudę Śląską. 


\begin{tabular}{|c|c|c|c|c|c|c|c|c|c|c|c|c|c|}
\hline Lp. & Miasto & 1 & 2 & 3 & 4 & 5 & 6 & 7 & 8 & 9 & 10 & 11 & 12 \\
\hline 1 & Bielsko-Biała & 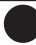 & 0 & 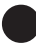 & $\bullet$ & $\bullet$ & $\cdot$ & & - & & $\bullet$ & $\bullet$ & $\bullet$ \\
\hline 2 & Częstochowa & 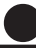 & & & 0 & 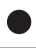 & $\cdot$ & & 0 & 0 & 0 & 0 & $\bullet$ \\
\hline 3 & Gliwice & $\mathrm{C}$ & & 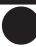 & 0 & 0 & 0 & $\bullet$ & O & 0 & $\bullet$ & • & 0 \\
\hline 4 & Dąbrowa Górnicza & $\bullet$ & 0 & 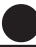 & 0 & 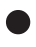 & $\bullet$ & $\bullet$ & $\bullet$ & $\bullet$ & $\bullet$ & - & $\cdot$ \\
\hline 5 & Tychy & $\bullet$ & 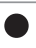 & 0 & 0 & O & $\bullet$ & $\bullet$ & • & • & & • & \\
\hline 6 & Rybnik & - & $\cdot$ & 0 & $\bullet$ & $\bullet$ & 0 & 0 & - & & & & \\
\hline 7 & Ruda Śląska & & & $\bullet$ & $\bullet$ & $\bullet$ & 0 & O & & 0 & & • & \\
\hline 8 & Zabrze & - & 0 & O & $\bullet$ & $\cdot$ & • & 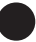 & & & & & \\
\hline 9 & Bytom & & 0 & O & $\bullet$ & $\cdot$ & & 0 & & & & 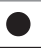 & \\
\hline 10 & Sosnowiec & $\bullet$ & 0 & $\bullet$ & $\bullet$ & & & & 0 & & & & • \\
\hline 11 & Chorzów & • & 0 & • & - & $\cdot$ & & $\cdot$ & $\mathcal{U}$ & 0 & & & \\
\hline 12 & Katowice & $\bullet$ & $\bullet$ & 0 & - & & & & & & • & & \\
\hline
\end{tabular}

\begin{tabular}{|l|l|l|l|l|l|l|l}
\hline $0-8,01$ & $\bigcirc$ & $8,01-8,734$ & $\bullet$ & $8,734-9,682$ & $\bullet$ & $9,682-10,733 \quad \square$ & $\square$
\end{tabular}

Rys. 1. Uporządkowany diagram Czekanowskiego dla zmiennych $X_{12}-X_{402}, 2002 \mathrm{r}$.

Źródło: opracowanie własne.

Tabela 2. Porównanie średnich grupowych ze średnią ogólną, zmienne $X_{12}-X_{402}, 2002 \mathrm{r}$.

\begin{tabular}{|c|c|c|c|c|c|c|c|c|c|c|c|c|c|c|c|c|}
\hline \multirow{2}{*}{$\begin{array}{l}\text { Grupa/ } \\
\text { zmienna }\end{array}$} & \multicolumn{16}{|c|}{ Iloraz średnich dla zmiennej } \\
\hline & $X_{12}$ & $X_{22}$ & $X_{32}$ & \multicolumn{2}{|c|}{$X_{42}$} & $X_{52}$ & $X_{62}$ & $X_{72}$ & $X_{82}$ & $X_{92}$ & \multicolumn{2}{|c|}{$X_{102}$} & $X_{112}$ & $X_{122}$ & $X_{132}$ & $X_{142}$ \\
\hline 1 & 1,091 & 1,019 & 0,861 & \multicolumn{2}{|c|}{0,923} & 0,951 & 1,286 & 1,971 & 0,888 & 1,096 & \multicolumn{2}{|c|}{0,350} & 0,543 & 1,105 & 1,499 & 2,759 \\
\hline 2 & 1,082 & 0,939 & 1,045 & \multicolumn{2}{|c|}{1,083} & 1,083 & 1,013 & 0,883 & 1,588 & 0,940 & \multicolumn{2}{|c|}{0,783} & 1,307 & 0,946 & 1,013 & 0,832 \\
\hline 3 & 0,806 & 1,028 & 0,999 & \multicolumn{2}{|c|}{0,990} & 0,957 & 0,718 & 0,427 & 0,706 & 0,976 & \multicolumn{2}{|c|}{0,823} & 0,810 & 1,027 & 70,789 & 0,409 \\
\hline 4 & 0,818 & 1,476 & 0,823 & 0,86 & & 0,852 & 0,999 & 0,487 & 0,551 & 1,084 & 0,8 & & 1,03 & 0,96 & 680,935 & 0,263 \\
\hline \multirow{2}{*}{$\begin{array}{l}\text { Grupa/ } \\
\text { zmienna }\end{array}$} & \multicolumn{16}{|c|}{ Iloraz średnich dla zmiennej } \\
\hline & \begin{tabular}{|l|}
$X_{152}$ \\
\end{tabular} & $X_{162}$ & $X_{172}$ & \multicolumn{2}{|c|}{$X_{182}$} & $X_{192}$ & $X_{202}$ & $X_{212}$ & $X_{222}$ & $X_{232}$ & $X_{2}$ & 42 & $X_{252}$ & $X_{26}$ & \begin{tabular}{l|l}
62 & $X_{272}$ \\
\end{tabular} & $X_{282}$ \\
\hline 1 & 0,770 & 0,660 & 0,897 & 0,77 & & 0,961 & 0,961 & 0,880 & 1,034 & 1,092 & 0,9 & \begin{tabular}{l|l}
38 & 1
\end{tabular} & 1,20 & 1,04 & \begin{tabular}{l|l}
44 & 1,532
\end{tabular} & $2,1,319$ \\
\hline 2 & 1,167 & 0,658 & 1,338 & 0,8 & & 0,652 & 0,765 & 0,854 & 1,036 & 1,025 & 1,3 & 310 & 0,94 & 0,78 & \begin{tabular}{l|l|l}
83 & 0,971
\end{tabular} & 10,943 \\
\hline 3 & 1,189 & 1,008 & 1,073 & 1,2 & & 1,005 & 1,229 & 1,272 & 0,617 & 0,689 & 1,0 & 641 & 1,38 & 1,03 & $\begin{array}{lll}31 & 0,584\end{array}$ & 40,951 \\
\hline 4 & 0,977 & 1,512 & 0,914 & 0,7 & & 1,321 & 1,243 & 1,038 & 0,943 & 1,013 & 1,2 & \begin{tabular}{l|l}
99 & 0
\end{tabular} & 0,58 & 1,31 & \begin{tabular}{l|l}
13 & 0,985
\end{tabular} & $\begin{array}{l}5 \\
0,650\end{array}$ \\
\hline Grupa/ & & & & & & & loraz & edni & dla & ienn & & & & & & \\
\hline & $X_{292}$ & $X_{302}$ & $X$ & & $X_{32}$ & & $X_{332}$ & $X_{342}$ & $X_{352}$ & $X_{362}$ & & $X_{372}$ & & $X_{382}$ & $X_{392}$ & $X_{402}$ \\
\hline 1 & 1,059 & $0,91^{\prime}$ & \begin{tabular}{l|l|}
7 & 0,7 \\
\end{tabular} & 84 & 0,98 & & 1,035 & 1,088 & 1,077 & 1,15 & & 1,01 & & 890 & 0,934 & 0,425 \\
\hline 2 & 1,069 & 0,76 & \begin{tabular}{l|l}
5 & 0,5
\end{tabular} & 880 & 0,94 & & 0,989 & 1,122 & 0,978 & 0,95 & & 0,92 & & ,929 & 0,932 & 0,425 \\
\hline 3 & 0,882 & 0,88 & \begin{tabular}{l|l}
6 & 1,2
\end{tabular} & 249 & 1,06 & & 0,980 & 0,744 & 0,938 & $0,77^{\prime}$ & & 1,02 & & ,987 & 1,087 & 1,640 \\
\hline 4 & 0,940 & 1,47 & \begin{tabular}{l|l}
0 & 1,5
\end{tabular} & 66 & 0,92 & & 1,017 & 2,347 & 0,946 & 1,17 & & 0,92 & &, 851 & 1,078 & 1,301 \\
\hline
\end{tabular}

Źródło: obliczenia własne. 
Ze względu na wszystkie cechy najkorzystniejsza sytuacja w 2002 r. wystąpiła (tabela 2) w grupie pierwszej (Bielsko-Biała i Częstochowa). Znacznie wyższe niż średnia dla 12 miast były tu: liczba mieszkań oddanych do użytku na 1000 ludności $\left(X_{142}\right)$, nakłady inwestycyjne na jednego mieszkańca w zł $\left(X_{72}\right)$ oraz liczba uczniów liceów ogólnokształcących na 1000 ludności $\left(X_{272}\right)$. O korzystnej sytuacji tej grupy miast świadczą także zmienne: emisja zanieczyszczeń gazowych $\left(X_{102}\right)$ i emisja zanieczyszczeń pyłowych $\left(X_{112}\right)$.

W drugiej grupie miast (Dąbrowa Górnicza i Gliwice) powyżej średniej dla 12 miast kształtowała się liczba ludności na jednego lekarza $\left(X_{152}\right)$, liczba ludności na jedną pielęgniarkę $\left(X_{172}\right)$ oraz liczba ludności na jedno miejsce w kinach stałych $\left(X_{242}\right)$. Powyżej średniej dla 12 miast kształtowała się natomiast wartość brutto środków trwałych na jednego mieszkańca $\left(X_{82}\right)$ i wartość współczynnika przyrostu naturalnego $\left(X_{342}\right)$.

W najbardziej niekorzystnej sytuacji znajdowały się miasta grupy trzeciej (Ruda Śląska, Zabrze i Bytom), dla których większość badanych zmiennych przybierała zdecydowanie niekorzystne wartości, i grupy IV (Sosnowiec i Chorzów), w której wystąpiła znacznie wyższa od średniej dla 12 miast liczba bezrobotnych na 1000 pracujących $\left(X_{22}\right)$, wyższa liczba ludności na jednego dentystę $\left(X_{16}\right)$ i większa gęstość zaludnienia $\left(X_{31}\right)$.

Ze względu na poziom zdrowotności i niektóre czynniki wpływające na jej poziom $\left(X_{152}-X_{202}, X_{92}-X_{112}, X_{312}, X_{382}-X_{392}\right.$ ) wyróżniono tylko jedną grupę miast, do której należą (zob. rys. 2): Bielsko-Biała, Częstochowa, Sosnowiec, Zabrze i Bytom, przy czym najmniejsze, pod względem wartości branych pod uwagę współczynników, różnice dzieliły w 2002 r. Bielsko-Białą i Częstochowę, a największe - Katowice i Rybnik (tabela 3). Wśród miast niewykazujących podobieństwa do innych badanych miast województwa śląskiego (Gliwice, Dąbrowa Górnicza, Ruda Śląska, Rybnik, Tychy, Katowice i Chorzów), które tworzyły grupy jednoelementowe, najgorszą sytuację ze względu na zdrowie, a w szczególności jego uwarunkowania, zaobserwowano w Rudzie Śląskiej, a najkorzystniejszą w Katowicach.

Badając poziom zamożności (zmienne $X_{32}-X_{82}, X_{122}-X_{142}, X_{292}-X_{302}$ ) wyróżniono grupy: 1) Sosnowiec i Częstochowa, 2) Bytom i Zabrze, 3) Rybnik i Ruda Śląska, 4) Katowice i Gliwice oraz grupy jednoelementowe: Bielsko-Biała, Dąbrowa Górnicza, Tychy i Chorzów (rys. 3). Najmniejsze pod tym względem różnice dzieliły w 2002 r. Bytom i Zabrze, największe - Chorzów i Bielsko-Białą. Można dostrzec (tabela 4), że w tym przypadku najkorzystniejsza sytuacja wystąpiła w grupie czwartej, do której należą Katowice i Gliwice - wszystkie cechy diagnostyczne (z wyjątkiem liczby mieszkań oddanych do użytku na 1000 ludności) miały tu wartości wyższe niż średnia dla 12 miast. Poniżej średniej dla 12 miast kształtowała się większość badanych cech dla grupy drugiej (Bytom i Zabrze), wyjątek stanowiła zmienna $X_{122}$, i dla grupy trzeciej (Rybnik i Ruda 
Śląska), wyjątkiem w tym przypadku były zmienne $X_{32}$ i $X_{52}$. Ponadto znacznie poniżej średniej dla 12 miast dla grupy drugiej miast kształtowały się zmienne: nakłady inwestycyjne na jednego mieszkańca $\left(X_{72}\right)$ i mieszkania oddane do użytku na 1000 ludności $\left(X_{142}\right)$, co świadczy o niekorzystnej pod tym względem sytuacji. Najkorzystniejsza sytuacja ze względu na cechy charakteryzujące poziom zamożności spośród miast niewykazujących podobieństwa do innych badanych była w Tychach, a najmniej korzystna w Chorzowie.

\begin{tabular}{|c|c|c|c|c|c|c|c|c|c|c|c|c|c|}
\hline Lp. & Miasto & 1 & 2 & 3 & 4 & 5 & 6 & 7 & 8 & 9 & 10 & 11 & 12 \\
\hline 1 & Bielsko-Biała & & & & & & 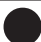 & $\bullet$ & - & & $\bullet$ & 0 & $\bullet$ \\
\hline 2 & Częstochowa & & & & 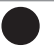 & & $O$ & 0 & • & & $\bullet$ & 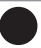 & - \\
\hline 3 & Sosnowiec & & & & & & 0 & • & - & & • & 0 & 0 \\
\hline 4 & Bytom & & & & 0 & 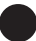 & 0 & $\bullet$ & $\bullet$ & & $\bullet$ & 0 & 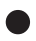 \\
\hline 5 & Zabrze & & 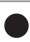 & & ) & 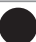 & 0 & - & $\bullet$ & • & - & 0 & 0 \\
\hline 6 & Gliwice & D & O & 0 & 0 & 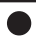 & 0 & - & $\bullet$ & • & $\bullet$ & $\bullet$ & \\
\hline 7 & Dąbrowa Górnicza & $\bullet$ & O & • & $\bullet$ & - & 0 & O & $\bullet$ & $\bullet$ & • & & \\
\hline 8 & Ruda Śląska & • & • & - & $\bullet$ & $\bullet$ & $\bullet$ & $\bullet$ & O & $\bullet$ & • & & - \\
\hline 9 & Rybnik & & & & & - & • & $\bullet$ & $\bullet$ & 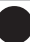 & & & \\
\hline 10 & Tychy & $\bullet$ & $\bullet$ & - & $\bullet$ & - & • & - & • & & D & & \\
\hline 11 & Katowice & ○ & 0 & 0 & 0 & 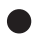 & $\bullet$ & & & & & & - \\
\hline 12 & Chorzów & $\bullet$ & • & 0 & 0 & 0 & & & - & & & • & \\
\hline & $0-3,543$ & 4,65 & . & & 5,428 & & 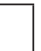 & $8-$ & & & $\geq 6$, & & \\
\hline
\end{tabular}

Rys. 2. Uporządkowany diagram Czekanowskiego dla zmiennych charakteryzujących poziom zdrowotności $X_{152}-X_{202}, X_{92}-X_{112}, X_{312}, X_{382}-X_{392}, 2002$ r.

Źródło: opracowanie własne.

Tabela 3. Porównanie średnich grupowych ze średnią ogólną, zmienne opisujące poziom zdrowotności i niektóre jego uwarunkowania $\left(X_{92}-X_{112}, X_{152}-X_{202}, X_{312}, X_{382}-X_{392}\right), 2002 \mathrm{r}$.

\begin{tabular}{|l|c|c|c|c|c|c|c|c|c|c|c|c|}
\hline \multirow{2}{*}{$\begin{array}{c}\text { Grupa/ } \\
\text { zmienna }\end{array}$} & \multicolumn{10}{|c|}{ Iloraz średnich dla zmiennej } \\
\cline { 2 - 3 } & $X_{92}$ & $X_{102}$ & $X_{112}$ & $X_{152}$ & $X_{162}$ & $X_{172}$ & $X_{182}$ & $X_{192}$ & $X_{312}$ & $X_{202}$ & $X_{382}$ & $X_{392}$ \\
\hline 1 & 1,055 & 0,406 & 0,498 & 0,939 & 0,778 & 0,893 & 0,914 & 1,101 & 1,129 & 1,141 & 0,835 & 0,979 \\
\hline \multicolumn{10}{|c|}{ Inne miasta } \\
\hline Katowice & 0,981 & 0,676 & 0,604 & 0,393 & 0,375 & 0,501 & 0,787 & 1,598 & 1,040 & 1,043 & 0,967 & 1,037 \\
\hline Ruda Śląska & 0,913 & 1,246 & 1,114 & 1,361 & 1,485 & 1,382 & 1,480 & 0,613 & 1,006 & 0,974 & 1,151 & 1,241 \\
\hline
\end{tabular}

Źródło: obliczenia własne. 


\begin{tabular}{|c|c|c|c|c|c|c|c|c|c|c|c|c|c|}
\hline Lp. & Miasto & 1 & 2 & 3 & 4 & 5 & 6 & 7 & 8 & 9 & 10 & 11 & 12 \\
\hline 1 & Bielsko-Biała & 0 & ○ & & & & & & & - & & $\bullet$ & \\
\hline 2 & Częstochowa & 0 & 0 & 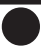 & 0 & 0 & - & • & • & $\bullet$ & & $\bullet$ & $\bullet$ \\
\hline 3 & Sosnowiec & & 0 & 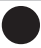 & & C & $\bullet$ & $\bullet$ & $\bullet$ & • & & $\bullet$ & C \\
\hline 4 & Bytom & & 0 & C & & & & $\bullet$ & $\bullet$ & • & & $\bullet$ & C \\
\hline 5 & Zabrze & & 0 & 0 & 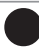 & 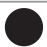 & 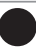 & $\bullet$ & 0 & 0 & • & $\bullet$ & 0 \\
\hline 6 & Ruda Śląska & & • & $\bullet$ & 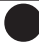 & 0 & 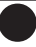 & & 0 & 0 & & & $\bullet$ \\
\hline 7 & Rybnik & & - & $\bullet$ & $\bullet$ & $\bullet$ & 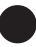 & $C$ & $C$ & ? & • & 0 & - \\
\hline 8 & Dąbrowa Górnicza & & • & $\bullet$ & $\bullet$ & 0 & 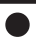 & $\mathrm{C}$ & 0 & 0 & • & 0 & • \\
\hline 9 & Gliwice & • & $\bullet$ & - & • & 0 & 0 & 0 & 0 & & & & . \\
\hline 10 & Katowice & & & & & • & & • & • & & $\mathrm{C}$ & $\bullet$ & \\
\hline 11 & Tychy & $\bullet$ & $\bullet$ & $\bullet$ & $\bullet$ & $\bullet$ & 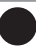 & 0 & 0 & $\mathrm{C}$ & $\bullet$ & 0 & • \\
\hline 12 & Chorzów & & $\bullet$ & $\cap$ & & 0 & $\bullet$ & - & • & • & & • & \\
\hline
\end{tabular}

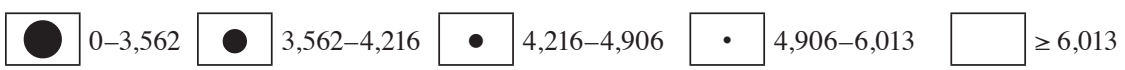

Rys. 3. Uporządkowany diagram Czekanowskiego dla zmiennych charakteryzujących poziom zamożności $X_{32}-X_{82}, X_{122}-X_{142}, X_{292}-X_{302}, 2002$ r.

Źródło: opracowanie własne.

Tabela 4. Porównanie średnich grupowych ze średnią ogólną, zmienne charakteryzujące poziom zamożności $X_{32}-X_{82}, X_{122}-X_{142}, X_{292}-X_{302}, 2002 \mathrm{r}$.

\begin{tabular}{|c|c|c|c|c|c|c|c|c|c|c|c|}
\hline \multirow{2}{*}{ Grupa/zmienna } & \multicolumn{10}{|c|}{ Iloraz średnich dla zmiennej } \\
\cline { 2 - 13 } & $X_{32}$ & $X_{42}$ & $X_{52}$ & $X_{62}$ & $X_{72}$ & $X_{82}$ & $X_{122}$ & $X_{132}$ & $X_{142}$ & $X_{292}$ & $X_{302}$ \\
\hline 1 & 0,837 & 0,845 & 0,865 & 1,120 & 0,784 & 0,603 & 1,088 & 1,120 & 1,095 & 1,046 & 1,075 \\
\hline 2 & 0,918 & 0,998 & 0,933 & 0,766 & 0,329 & 0,612 & 1,089 & 0,833 & 0,350 & 0,876 & 0,839 \\
\hline 3 & 1,173 & 0,995 & 1,036 & 0,766 & 0,620 & 0,971 & 0,831 & 0,679 & 0,788 & 0,994 & 0,836 \\
\hline 4 & 1,120 & 1,241 & 1,194 & 1,174 & 1,207 & 1,421 & 1,091 & 1,085 & 0,964 & 1,144 & 1,153 \\
\hline \multicolumn{10}{|c|}{ Inne miasta } \\
\hline Chorzów & 0,799 & 0,873 & 0,866 & 0,876 & 0,630 & 0,591 & 0,921 & 0,991 & 0,175 & 0,783 & 1,681 \\
\hline Tychy & 1,219 & 0,983 & 1,031 & 1,026 & 2,087 & 1,268 & 0,959 & 1,105 & 1,226 & 0,970 & 1,023 \\
\hline
\end{tabular}

Źródło: obliczenia własne.

Ze względu na poziom kultury i edukacji (zmienne $X_{232}-X_{282}$ ) można wśród badanych miast województwa śląskiego wyróżnić osiem grup miast: 1) Bielsko-Biała i Częstochowa, 2) Tychy, Gliwice, Chorzów i Rybnik oraz sześć grup 
jednoelementowych: Zabrze, Ruda Śląska, Bytom, Dąbrowa Górnicza, Katowice i Sosnowiec, przy czym najmniejsze różnice dzieliły Chorzów i Tychy, a największe - Katowice i Bytom (rys. 4). Lepszą pod tym względem sytuację odnotowano w Bielsku-Białej i Częstochowie (grupa pierwsza), dla których prawie wszystkie zmienne miały wartości wyższe niż średnia dla 12 miast (tabela 5), wyjątek stanowiła zmienna $X_{242}$ - liczba ludności na jedno miejsce w kinach stałych. Natomiast w grupie drugiej powyżej średniej dla 12 miast kształtowały się cechy świadczące o poziomie edukacji: liczba uczniów liceów ogólnokształcących i uczniów ponadgimnazjalnych zasadniczych szkół zawodowych na 1000 ludności.

\begin{tabular}{|c|c|c|c|c|c|c|c|c|c|c|c|c|c|}
\hline Lp. & Miasto & 1 & 2 & 3 & 4 & 5 & 6 & 7 & 8 & 9 & 10 & 11 & 12 \\
\hline 1 & Bielsko-Biała & 0 & 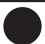 & - & - & - & 0 & - & - & & - & - & \\
\hline 2 & Częstochowa & 0 & 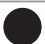 & 0 & 0 & - & 0 & - & - & & - & - & - \\
\hline 3 & Tychy & - & 0 & O & O & O & $\mathbf{0}$ & 0 & - & & - & - & - \\
\hline 4 & Chorzów & - & & 0 & 0 & 0 & - & 0 & - & - & - & - & $\bullet$ \\
\hline 5 & Gliwice & - & - & 0 & 0 & 0 & 0 & • & - & - & - & - & \\
\hline 6 & Rybnik & 0 & 0 & 0 & - & 0 & 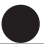 & - & - & & - & - & \\
\hline 7 & Zabrze & - & - & O & 0 & - & - & 0 & - & - & - & - & - \\
\hline 8 & Ruda Śląska & - & - & - & - & - & - & - & P & - & - & & \\
\hline 9 & Bytom & & & & - & - & & - & - & D & & & \\
\hline 10 & Dąbrowa Górnicza & - & • & - & - & - & - & - & - & & 0 & e & - \\
\hline 11 & Katowice & - & - & - & - & - & - & - & & & - & 0 & \\
\hline 12 & Sosnowiec & & - & - & - & & & - & & & - & & \\
\hline
\end{tabular}

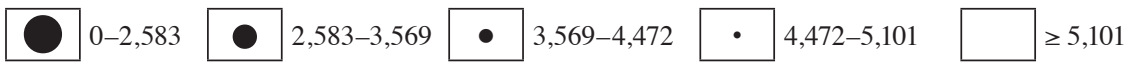

Rys. 4. Uporządkowany diagram Czekanowskiego dla zmiennych charakteryzujących poziom kultury i edukacji $X_{232}-X_{282}, 2002 \mathrm{r}$.

Źródło: opracowanie własne.

Tabela 5. Porównanie średnich grupowych ze średnią ogólną, zmienne charakteryzujące poziom kultury i edukacji $X_{232}-X_{282}, 2002 \mathrm{r}$.

\begin{tabular}{|c|c|c|c|c|c|c|}
\hline \multirow{2}{*}{ Grupa/zmienna } & \multicolumn{7}{|c|}{ Iloraz średnich dla zmiennej } \\
\cline { 2 - 7 } & $X_{232}$ & $X_{242}$ & $X_{252}$ & $X_{262}$ & $X_{272}$ & $X_{282}$ \\
\hline 1 & 1,092 & 0,938 & 1,200 & 1,044 & 1,532 & 1,319 \\
\hline 2 & 0,992 & 0,779 & 0,595 & 0,832 & 1,097 & 1,185 \\
\hline
\end{tabular}

Źródło: obliczenia własne. 


\section{Podobieństwo miast w 2009 roku}

Ze względu na wszystkie zmienne diagnostyczne (zmienne $X_{19}-X_{409}$ ) dla 2009 r. wyróżniono grupy miast: 1) Bielsko-Biała i Częstochowa, 2) Sosnowiec, Zabrze i Gliwice oraz grupy jednoelementowe: Bytom, Ruda Śląska, Chorzów, Rybnik, Tychy, Dąbrowa Górnicza i Katowice (rys. 5).

Najmniejsze różnice dzieliły w 2009 r. Bielsko-Białą i Częstochowę, a największe - Katowice i Rybnik. Bardziej niekorzystna sytuacja ze względu na cechy $X_{19}-X_{409}$ (tabela 6) wystąpiła w grupie drugiej (Sosnowiec, Zabrze i Gliwice). Znacznie wyższe niż średnia dla 12 miast okazały się w tym przypadku: współczynnik zgonów niemowląt $\left(X_{209}\right)$, liczba bezrobotnych na 1000 pracujących $\left(X_{29}\right)$, gęstość zaludnienia $\left(X_{319}\right)$, liczba ludności na jednego lekarza i na jedną pielęgniarkę ( $X_{159}$ i $X_{179}$ ), na korzyść tej grupy miast świadczy natomiast wartość współczynnika przyrostu naturalnego $\left(X_{349}\right)$.

W grupie pierwszej (Bielsko-Biała i Częstochowa) powyżej średniej dla 12 miast kształtowały się: liczba mieszkań oddanych do użytkowania na 1000 ludności $\left(X_{149}\right)$, zużycie gazu w gospodarstwach domowych na jednego mieszkańca $\left(X_{139}\right)$, liczba podmiotów zarejestrowanych w rejestrze Regon na 10 tys. ludności $\left(X_{69}\right)$, liczba uczniów liceów ogólnokształcących i ponadgimnazjalnych zasadniczych szkół zawodowych $\left(X_{279}\right.$ i $\left.X_{289}\right)$, liczba pracujących ogółem na 1000 ludności $\left(X_{19}\right)$ - zmienne świadczące o poziomie zamożności i poziomie edukacji.

\begin{tabular}{|c|c|c|c|c|c|c|c|c|c|c|c|c|c|}
\hline Lp. & Miasto & 1 & 2 & 3 & 4 & 5 & 6 & 7 & 8 & 9 & 10 & 11 & 12 \\
\hline 1 & Bielsko-Biała & & & - & & - & & & - & - & & - & 0 \\
\hline 2 & Częstochowa & & & & & 0 & $\bullet$ & $\bullet$ & 0 & & & $\bullet$ & $\bullet$ \\
\hline 3 & Sosnowiec & - & & 0 & & 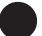 & C & 0 & 0 & & & - & - \\
\hline 4 & Gliwice & 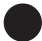 & & & & & - & - & - & $\bullet$ & O & 0 & $\bullet$ \\
\hline 5 & Zabrze & $\bullet$ & O & 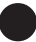 & & & 0 & 0 & 0 & $\bullet$ & 0 & 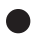 & \\
\hline 6 & Bytom & & - & 0 & - & O & 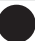 & 0 & 0 & & & & \\
\hline 7 & Ruda Śląska & & $\bullet$ & 0 & $\cdot$ & 0 & 0 & O & 0 & $\bullet$ & $\cdot$ & $\cdot$ & \\
\hline 8 & Chorzów & • & 0 & 0 & • & 0 & 0 & 0 & O & - & • & • & \\
\hline 9 & Rybnik & $\cdot$ & & & $\bullet$ & $\bullet$ & & $\bullet$ & $\bullet$ & 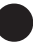 & $\bullet$ & • & \\
\hline 10 & Tychy & $\mathrm{O}$ & & & & 0 & & - & $\cdot$ & $\bullet$ & 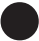 & $\bullet$ & - \\
\hline 11 & Dąbrowa Górnicza & • & $\bullet$ & $\bullet$ & ( & 0 & & - & - & • & $\bullet$ & & \\
\hline 12 & Katowice & 0 & $\bullet$ & $\bullet$ & • & & & & & & - & & \\
\hline
\end{tabular}

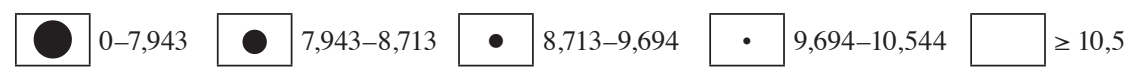

Rys. 5. Uporządkowany diagram Czekanowskiego dla wszystkich zmiennych $X_{19}-X_{409}, 2009$ r. Źródło: opracowanie własne. 
Tabela 6. Porównanie średnich grupowych ze średnią ogólną, wszystkie zmienne diagnostyczne $X_{19}-X_{409}, 2009 \mathrm{r}$.

\begin{tabular}{|c|c|c|c|c|c|c|c|c|c|c|c|c|c|c|}
\hline \multirow{2}{*}{$\begin{array}{c}\text { Grupa/ } \\
\text { zmienna }\end{array}$} & \multicolumn{10}{|c|}{ Iloraz średnich dla zmiennej } \\
\cline { 2 - 3 } & $X_{19}$ & $X_{29}$ & $X_{39}$ & $X_{49}$ & $X_{59}$ & $X_{69}$ & $X_{79}$ & $X_{89}$ & $X_{99}$ & $X_{109}$ & $X_{119}$ & $X_{129}$ & $X_{139}$ & $X_{149}$ \\
\hline 1 & 1,157 & 0,854 & 0,945 & 1,002 & 0,967 & 1,201 & 1,126 & 0,874 & 1,076 & 0,312 & 0,700 & 1,133 & 1,568 & 1,623 \\
\hline 2 & 0,884 & 1,160 & 1,009 & 1,014 & 1,015 & 0,999 & 0,892 & 0,872 & 0,915 & 0,259 & 0,569 & 1,003 & 0,948 & 0,918 \\
\hline & \multicolumn{10}{|c|}{ Iloraz średnich dla zmiennej } \\
\hline $\begin{array}{c}\text { Grupa/ } \\
\text { zmienna }\end{array}$ & $X_{159}$ & $X_{169}$ & $X_{179}$ & $X_{189}$ & $X_{199}$ & $X_{209}$ & $X_{219}$ & $X_{229}$ & $X_{239}$ & $X_{249}$ & $X_{259}$ & $X_{269}$ & $X_{279}$ & $X_{289}$ \\
\hline 1 & 0,750 & 0,742 & 0,873 & 0,708 & 1,060 & 0,696 & 0,859 & 0,950 & 1,221 & 0,807 & 1,036 & 0,845 & 1,617 & 1,340 \\
\hline 2 & 1,017 & 0,994 & 1,043 & 0,949 & 0,941 & 1,396 & 1,028 & 0,836 & 0,967 & 0,698 & 0,831 & 1,146 & 0,819 & 0,884 \\
\hline & \multicolumn{10}{|c|}{ Iloraz średnich dla zmiennej } & & & \\
\hline $\begin{array}{c}\text { Grupa/ } \\
\text { zmienna }\end{array}$ & $X_{299}$ & $X_{309}$ & $X_{319}$ & $X_{329}$ & $X_{339}$ & $X_{349}$ & $X_{359}$ & $X_{369}$ & $X_{379}$ & $X_{389}$ & $X_{399}$ & $X_{409}$ \\
\hline 1 & 1,051 & 0,906 & 0,790 & 0,999 & 1,035 & 0,362 & 0,997 & 1,147 & 1,024 & 0,940 & 0,922 & 0,961 \\
\hline 2 & 1,009 & 1,017 & 1,124 & 0,952 & 1,000 & 2,303 & 0,951 & 1,002 & 0,927 & 0,951 & 0,967 & 1,219 \\
\hline
\end{tabular}

Źródło: obliczenia własne.

\begin{tabular}{|c|c|c|c|c|c|c|c|c|c|c|c|c|c|}
\hline Lp. & Miasto & 1 & 2 & 3 & 4 & 5 & 6 & 7 & 8 & 9 & 10 & 11 & 12 \\
\hline 1 & Bielsko-Biała & 0 & & 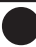 & 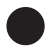 & 0 & 0 & $\bullet$ & 0 & $\cdot$ & - & & - \\
\hline 2 & Częstochowa & & & 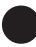 & 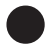 & & & 0 & 0 & - & - & & • \\
\hline 3 & Tychy & 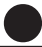 & 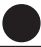 & 0 & 0 & $\bullet$ & $\bullet$ & $\cdot$ & $\bullet$ & $\bullet$ & • & $\bullet$ & - \\
\hline 4 & Zabrze & $J$ & & 0 & & & & $\bullet$ & 0 & $\bullet$ & $\bullet$ & $\bullet$ & \\
\hline 5 & Sosnowiec & 0 & & $\bullet$ & & & & 0 & 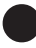 & 0 & 0 & & • \\
\hline 6 & Bytom & 0 & 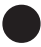 & $\bullet$ & 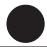 & 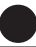 & & 0 & 0 & $\bullet$ & 0 & & • \\
\hline 7 & Katowice & $\bullet$ & 0 & - & $\bullet$ & ○ & P & 0 & $\bullet$ & & & & \\
\hline 8 & Gliwice & 0 & 0 & $\bullet$ & C & 0 & 0 & $\bullet$ & P & $\bullet$ & & & - \\
\hline 9 & Ruda Śląska & - & - & $\bullet$ & $\bullet$ & 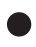 & $\bullet$ & & $\bullet$ & 0 & 0 & - & $\bullet$ \\
\hline 10 & Chorzów & • & • & • & $\bullet$ & 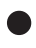 & 0 & & & 0 & & & \\
\hline 11 & Rybnik & & & $\bullet$ & $\bullet$ & & & & & • & & 0 & $\bullet$ \\
\hline 12 & Dąbrowa Górnicza & • & • & • & & $\cdot$ & - & & • & $\bullet$ & & $\bullet$ & \\
\hline
\end{tabular}

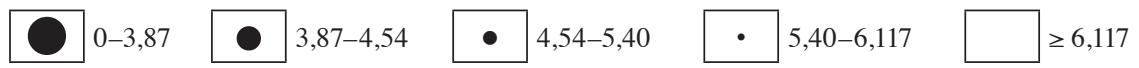

Rys. 6. Uporządkowany diagram Czekanowskiego dla zmiennych charakteryzujących poziom zdrowotności $X_{99}-X_{119}, X_{159}-X_{209}, X_{319}, X_{389}-X_{399}, 2009$ r.

Źródło: opracowanie własne. 
Ze względu na zmienne charakteryzujące poziom zdrowotności i jego niektóre uwarunkowania w 2009 r. wyróżniono grupy miast: 1) Bielsko-Biała, Częstochowa i Tychy, 2) Sosnowiec, Zabrze i Bytom oraz grupy jednoelementowe: Katowice, Gliwice, Ruda Śląska, Chorzów, Rybnik i Dąbrowa Górnicza (rys. 6). Najmniejsze różnice dzieliły Bielsko-Białą i Częstochowę, a największe - Katowice i Rybnik. Korzystna sytuacja (zob. tabela 8) wystąpiła w grupie pierwszej (Bielsko-Biała, Częstochowa i Tychy). Wyższy od średniej dla 12 miast był współczynnik ścieków oczyszczonych $\left(X_{92}\right)$ oraz liczba łóżek w szpitalach na 10 tys. ludności $\left(X_{192}\right)$, pozostałe zmienne przybrały wartości poniżej średniej dla 12 miast. Miasta grupy drugiej (Sosnowiec, Zabrze i Bytom) zdecydowanie niekorzystnie wypadły natomiast pod względem wartości współczynnika zgonów niemowląt, gęstości zaludnienia i standaryzowanego współczynnika zgonów kobiet.

Tabela 7. Porównanie średnich grupowych ze średnią ogólną, zmienne charakteryzujące poziom zdrowotności $X_{99}-X_{119}, X_{159}-X_{209}, X_{319}, X_{389}-X_{399}, 2009$ r.

\begin{tabular}{|l|c|c|c|c|c|c|c|c|c|c|c|c|}
\hline \multirow{2}{*}{ Grupa/zmienna } & \multicolumn{10}{|c|}{ Iloraz średnich dla zmiennej } \\
\cline { 2 - 13 } & $X_{99}$ & $X_{109}$ & $X_{119}$ & $X_{159}$ & $X_{169}$ & $X_{179}$ & $X_{189}$ & $X_{199}$ & $X_{319}$ & $X_{209}$ & $X_{389}$ & $X_{399}$ \\
\hline 1 & 1,078 & 0,340 & 0,581 & 0,815 & 0,878 & 0,917 & 0,851 & 1,043 & 0,814 & 0,565 & 0,925 & 0,897 \\
\hline \multicolumn{10}{|c|}{ Inne miasta } \\
\hline Katowice & 0,989 & 0,320 & 0,869 & 0,978 & 0,935 & 0,928 & 0,967 & 1,140 & 1,336 & 1,372 & 0,994 & 1,025 \\
\hline Ruda Śląska & 0,800 & 0,514 & 0,771 & 0,451 & 0,685 & 0,471 & 0,758 & 1,661 & 1,018 & 1,162 & 1,007 & 1,023 \\
\hline Rybnik & 0,974 & 0,498 & 0,678 & 1,094 & 1,302 & 1,491 & 1,258 & 0,530 & 1,003 & 0,798 & 1,208 & 1,138 \\
\hline Dąbrowa Górnicza & 1,077 & 2,368 & 3,365 & 1,394 & 0,855 & 1,331 & 0,896 & 0,585 & 0,368 & 0,812 & 1,046 & 1,087 \\
\hline
\end{tabular}

Źródło: obliczenia własne.

Ze względu na poziom zamożności (zmienne $X_{39}-X_{89}, X_{129}-X_{149}, X_{299}-X_{309}$ ) można wśród badanych miast województwa śląskiego wyróżnić grupy: 1) Dąbrowa Górnicza i Gliwice, 2) Rybnik, Ruda Śląska, Bytom i Chorzów, 3) Sosnowiec i Częstochowa oraz grupy jednoelementowe: Bielsko-Biała, Tychy, Katowice i Zabrze, przy czym najmniejsze różnice dzieliły Bytom i Rudę Śląską, a największe - Katowice i Bytom (rys. 7).

Najkorzystniejsza sytuacja pod względem zamożności wystąpiła w pierwszej grupie miast (Gliwice i Dąbrowa Górnicza); prawie wszystkie cechy miały wartości wyższe niż średnia dla 12 miast, wyjątek stanowią cechy: $X_{59}$ - wydatki budżetu miasta na jednego mieszkańca, $X_{129}$ - zużycie wody w gospodarstwie domowym na jednego mieszkańca, oraz $X_{309}$ - drogi publiczne powiatowe o twardej nawierzchni (tabela 8). 


\begin{tabular}{|c|c|c|c|c|c|c|c|c|c|c|c|c|c|}
\hline Lp. & Miasto & 1 & 2 & 3 & 4 & 5 & 6 & 7 & 8 & 9 & 10 & 11 & 12 \\
\hline 1 & Bielsko-Biała & 0 & & $\cdot$ & - & & & & $\cdot$ & 0 & $\bullet$ & 0 & \\
\hline 2 & Gliwice & 0 & 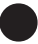 & O & 0 & • & - & - & $\bullet$ & 0 & 0 & 0 & $\cdot$ \\
\hline 3 & Dąbrowa Górnicza & • & 0 & 0 & 0 & $\bullet$ & $\bullet$ & $\bullet$ & • & $\bullet$ & $\bullet$ & • & $\bullet$ \\
\hline 4 & Rybnik & • & 0 & O & 0 & & & 0 & $\bullet$ & 0 & $\cdot$ & & 0 \\
\hline 5 & Ruda Śląska & & • & $\bullet$ & 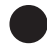 & 2 & & & 0 & 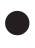 & & & 0 \\
\hline 6 & Bytom & & • & $\bullet$ & ) & 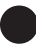 & & & & 0 & & & 0 \\
\hline 7 & Chorzów & & $\cdot$ & $\bullet$ & 0 & 0 & 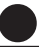 & & & $\bullet$ & & & $\bullet$ \\
\hline 8 & Sosnowiec & $\cdot$ & $\bullet$ & • & $\bullet$ & 0 & O & 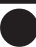 & 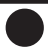 & 0 & & & $\cdot$ \\
\hline 9 & Częstochowa & 0 & 0 & $\bullet$ & 0 & 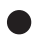 & 0 & $\bullet$ & & 0 & $\bullet$ & • & • \\
\hline 10 & Tychy & $\bullet$ & 0 & $\bullet$ & • & & & & & $\bullet$ & 0 & $\bullet$ & $\bullet$ \\
\hline 11 & Katowice & 0 & 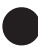 & • & & & & & & • & $\bullet$ & 0 & \\
\hline 12 & Zabrze & & - & $\bullet$ & 0 & 0 & 0 & $\bullet$ & • & - & $\bullet$ & & \\
\hline
\end{tabular}

Rys. 7. Uporządkowany diagram Czekanowskiego dla zmiennych charakteryzujących poziom zamożności $X_{39}-X_{89}, X_{129}-X_{149}, X_{299}-X_{309}, 2009$ r.

Źródło: opracowanie własne.

Tabela 8. Porównanie średnich grupowych ze średnią ogólną, zmienne charakteryzujące poziom zamożności $X_{39}-X_{89}, X_{129}-X_{149}, X_{299}-X_{309}, 2009$ r.

\begin{tabular}{|l|c|c|c|c|c|c|c|c|c|c|c|}
\hline \multirow{2}{*}{ Grupa/zmienna } & \multicolumn{10}{|c|}{ Iloraz średnich dla zmiennej } \\
\cline { 2 - 13 } & $X_{39}$ & $X_{49}$ & $X_{59}$ & $X_{69}$ & $X_{79}$ & $X_{89}$ & $X_{129}$ & $X_{139}$ & $X_{149}$ & $X_{299}$ & $X_{309}$ \\
\hline 1 & 1,120 & 1,028 & 0,944 & 1,028 & 1,307 & 1,627 & 0,947 & 1,000 & 1,254 & 1,094 & 0,663 \\
\hline 2 & 0,906 & 0,892 & 0,901 & 0,843 & 0,610 & 0,628 & 0,895 & 0,778 & 0,504 & 0,898 & 1,058 \\
\hline 3 & 0,903 & 0,822 & 0,815 & 1,056 & 0,573 & 0,584 & 1,148 & 0,994 & 1,131 & 1,018 & 1,206 \\
\hline \multicolumn{10}{|c|}{ Inne miasta } \\
\hline Bielsko-Biała & 1,001 & 1,112 & 1,220 & 1,343 & 1,487 & 1,134 & 1,087 & 1,931 & 1,770 & 1,092 & 0,953 \\
\hline Zabrze & 0,991 & 1,238 & 1,438 & 0,828 & 0,692 & 0,659 & 0,889 & 0,945 & 0,197 & 0,869 & 0,691 \\
\hline Katowice & 1,378 & 1,180 & 1,278 & 1,303 & 1,573 & 1,527 & 1,144 & 1,133 & 1,525 & 1,205 & 1,335 \\
\hline
\end{tabular}

Źródło: obliczenia własne.

Poniżej średniej dla 12 miast (sytuacja niekorzystna) kształtowała się większość badanych cech dla grupy drugiej (Rybnik, Ruda Śląska, Bytom, Chorzów i Sosnowiec), wyjątek stanowiła tu zmienna $X_{309}$ - drogi publiczne powiatowe o twardej nawierzchni. Spośród miast, które nie zostały przydzielone do żadnej grupy, najkorzystniejszą sytuację pod względem poziomu zamożności (i bardziej 
korzystną niż w grupie pierwszej) zaobserwowano w Katowicach i Bielsku-Białej, a najgorszą w Zabrzu.

Rozpatrując poziom kultury i edukacji $\left(X_{239}-X_{289}\right)$ można wyróżnić grupy miast: 1) Bielsko-Biała i Rybnik, 2) Tychy i Gliwice, 3) Zabrze, Sosnowiec i Dąbrowa Górnicza oraz grupy jednoelementowe: Chorzów, Częstochowa, Katowice, Ruda Śląska i Bytom, przy czym najmniejsze różnice dzieliły Gliwice i Zabrze, a największe - Katowice i Bytom (rys. 8).

\begin{tabular}{|c|c|c|c|c|c|c|c|c|c|c|c|c|c|}
\hline Lp. & Miasto & 1 & 2 & 3 & 4 & 5 & 6 & 7 & 8 & 9 & 10 & 11 & 12 \\
\hline 1 & Bielsko-Biała & & 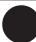 & & 0 & $\bullet$ & - & $\bullet$ & $\bullet$ & O & $\bullet$ & $\cdot$ & \\
\hline 2 & Rybnik & 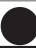 & 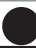 & 0 & 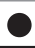 & • & - & - & $\bullet$ & 0 & & - & \\
\hline 3 & Tychy & $\mathcal{U}$ & 0 & & & & 0 & & ○ & 0 & • & • & \\
\hline 4 & Gliwice & 0 & 0 & & & & & & 0 & 0 & • & $\bullet$ & \\
\hline 5 & Zabrze & $\bullet$ & $\bullet$ & 0 & & & & & 0 & $\bullet$ & • & 0 & \\
\hline 6 & Sosnowiec & - & • & O & & & 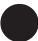 & & 0 & • & $\bullet$ & 0 & \\
\hline 7 & Dąbrowa Górnicza & $\bullet$ & - & 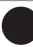 & & 0 & 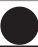 & & $\bullet$ & $\bullet$ & $\bullet$ & • & \\
\hline 8 & Chorzów & $\bullet$ & $\bullet$ & 0 & 0 & 0 & 0 & $\bullet$ & 0 & 0 & & $\bullet$ & $\bullet$ \\
\hline 9 & Częstochowa & 0 & 0 & 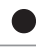 & 0 & $\bullet$ & $\cdot$ & $\bullet$ & 0 & 0 & • & & \\
\hline 10 & Katowice & $\bullet$ & & - & $\cdot$ & - & $\bullet$ & $\bullet$ & & • & & & \\
\hline 11 & Ruda Śląska & $\cdot$ & • & - & $\bullet$ & & 0 & • & • & & & & • \\
\hline 12 & Bytom & & & & & & & & $\bullet$ & & & • & \\
\hline
\end{tabular}

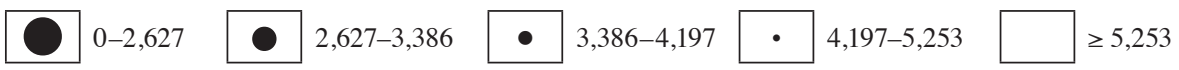

Rys. 8. Uporządkowany diagram Czekanowskiego dla zmiennych charakteryzujących poziom kultury i edukacji $X_{239}-X_{289}, 2009$ r.

Źródło: opracowanie własne.

Tabela 9. Porównanie średnich grupowych ze średnią ogólną, zmienne charakteryzujące poziom kultury i edukacji $X_{239}-X_{289}, 2009$ r.

\begin{tabular}{|c|c|c|c|c|c|c|}
\hline \multirow{2}{*}{ Grupa/zmienna } & \multicolumn{7}{|c|}{ Iloraz średnich dla zmiennej } \\
\cline { 2 - 7 } & $X_{239}$ & $X_{249}$ & $X_{259}$ & $X_{269}$ & $X_{279}$ & $X_{289}$ \\
\hline 1 & 1,215 & 0,661 & 0,984 & 0,797 & 1,194 & 1,688 \\
\hline 2 & 1,006 & 0,798 & 0,812 & 0,884 & 0,954 & 1,047 \\
\hline 3 & 1,003 & 0,718 & 0,862 & 1,124 & 0,808 & 0,610 \\
\hline Bytom & 0,346 & 3,288 & 1,497 & 1,030 & 0,654 & 0,847 \\
\hline Częstochowa & 1,048 & 0,665 & 0,953 & 0,893 & 1,884 & 1,162 \\
\hline
\end{tabular}

Źródło: obliczenia własne. 
W pierwszej grupie (Bielsko-Biała i Rybnik) poziom trzech zmiennych ( $\mathrm{tj}$. przypadającej na 1000 ludności liczby czytelników $-X_{239}$, liczby uczniów liceów ogólnokształcących $-X_{279}$, i uczniów ponadgimnazjalnych zasadniczych szkół zawodowych $-X_{289}$ ) był zdecydowanie wyższy niż średnia dla 12 miast (tabela 9). W grupie trzeciej (Zabrze, Sosnowiec i Dąbrowa Górnicza) przypada zdecydowanie więcej uczniów gimnazjum na jeden komputer z dostępem do internetu niż średnio dla 12 miast. Wśród miast nienależących do żadnej z grup najlepsza sytuacja pod względem poziomu kultury i edukacji była w Częstochowie, a najgorsza w Bytomiu.

\section{Podsumowanie}

Na podstawie przeprowadzonej analizy można uznać, że najbardziej podobnymi do siebie, a także najlepszymi pod względem sytuacji społeczno-gospodarczej i demograficznej były zarówno w 2002 r., jak i w 2009 r., mimo dzielącej je sporej odległości geograficznej, Bielsko-Biała i Częstochowa - miasta leżące poza obszarem byłego Górnośląskiego Okręgu Przemysłowego, na terenach zielonych województwa śląskiego. Cechowały się one najkorzystniejszymi na ogół wartościami całego zbioru zmiennych diagnostycznych, jak również zbiorów obejmujących zmienne charakteryzujące sytuację zdrowotną miast i jej uwarunkowania oraz poziomu kultury i edukacji. Miasto Bielsko-Biała cechowało się ponadto wysokim poziomem zamożności, nie wykazując jednak w tym względzie podobieństwa do innych miast.

Najbardziej podobnymi do siebie, a zarazem będącymi w niekorzystnej sytuacji miastami były: Sosnowiec, Zabrze i Gliwice - miasta leżące na terenie byłego Górnośląskiego Okręgu Przemysłowego.

Stosując metodę Czekanowskiego do badania zagadnień społeczno-demograficznych, warto zwrócić także uwagę na obiekty niepodobne do innych, co może okazać się ważne dla wyjaśniania przyczyn podobieństwa i odmienności badanych miast.

\section{Literatura}

Czekanowski J. [1909], Zur Differentialdiagnose der Neandertalgruppe, Korespondenz-Blatt der deutschen Gesellschaft für Anthropologie, Ethnologie und Urgeschichte, Braunschweig, vol. 40.

Czekanowski J. [1913], Zarys metod statystycznych w zastosowaniu do antropologii, Prace Naukowego Towarzystwa Warszawskiego, nr 5.

Heffner K., Gibas P. [2007], Analiza ekonomiczno-przestrzenna, Wydawnictwo Akademii Ekonomicznej w Katowicach, Katowice. 
Lipieta A. i in. [2000], Taksonomiczna analiza przestrzennego zróżnicowania poziomu życia w Polsce w ujęciu dynamicznym, Wydawnictwo Akademii Ekonomicznej w Krakowie, Kraków.

Mielecka-Kubień Z., Warzecha K. [2010], Poziom rozwoju społeczno-gospodarczego dużych miast woj. ślqskiego i jego uwarunkowania, Sprawozdanie z Badań Statutowych Katedry Ekonometrii Uniwersytetu Ekonomicznego w Katowicach (maszynopis).

Pociecha J. i in. [1988], Metody taksonomiczne w badaniach społeczno-ekonomicznych, PWN, Warszawa.

Pluta W. [1986], Wielowymiarowa analiza porównawcza w modelowaniu ekonometrycznym, PWN, Warszawa.

Wolny R. [2009], Metody ilościowe w badaniach rynku, Wydawnictwo Akademii Ekonomicznej w Katowicach, Katowice.

\section{The Socio-Demographic Situation of Chosen Cities in Śląskie Province in the Years 2002 and 2009}

The purpose of the research was to determine the similarities that exist among cities in the province of Śląskie with more than 100,000 inhabitants in the interval of a few years. The cities considered were Bielsko-Biała, Bytom, Chorzów, Częstochowa, Dąbrowa Górnicza, Gliwice, Katowice, Ruda Śląska, Rybnik, Sosnowiec, Tychy and Zabrze, all of which are located within close geographical proximity to one another.

The similarity of the cities was analysed according to chosen socio-economic indicators and demographic coefficients in the years 2002 and 2009. J. Czekanowski method was applied; to determine which groups of cities were better or worse off with regard to the given profile of the investigation, the average values of the indicators for the entire set of the cities, and for its established groups were compared.

The research was conducted in the following profiles: I - socio-demographic situation, II - population health and its determinants, III - affluence, IV - educational and cultural level. The cities that were the most similar to each other, and in the best socioeconomic and demographic situation were, for both years, and in spite of the relatively big geographic distance, Bielsko-Biała and Częstochowa. Bielsko-Biała stood alone among the cities for its affluence. Sosnowiec, Zabrze and Gliwice - all cities in the former UpperSilesian Industrial District - were similar to each other insofar as they were in the worst situation.

Keywords: J. Czekanowski's method, the socio-demographic situation, cities in Śląskie Province, taxonomic methods. 